\title{
The Impacts of Electronic Word of Mouth on Brand Equity in the Context of Social Media
}

\author{
Erfan Severi ${ }^{1}$, Kwek Choon Ling ${ }^{1} \&$ Amir Nasermoadeli ${ }^{1}$ \\ ${ }^{1}$ Faculty of Business and Information Science, UCSI University, Kuala Lumpur, Malaysia \\ Correspondence: Kwek Choon Ling, Faculty of Business and Information Technology, UCSI University, No.1, \\ Jalan Menara Gading, UCSI Heights, 56000 Kuala Lumpur, Malaysia. Tel: 60-016-688-6248. E-mail: \\ ckwek45@yahoo.com.my
}

Received: April 3, 2014

doi:10.5539/ijbm.v9n8p84
Accepted: May 26, $2014 \quad$ Online Published: July 25, 2014

URL: http://dx.doi.org/10.5539/ijbm.v9n8p84

\begin{abstract}
Social media has become the driving force which transforms the web into an interactive information and communications technology device. Social media has a significant role in influencing customer's choice in selecting products and services based on the customers' feedbacks that appeared in the weblogs, web sites, online boards and other kinds of user-generated content (Raman, 2009). It is indeed important to remember that brand equity is no longer valued by large sums of money that companies invest; instead customers are dictating the value of brand equity by what they are saying to each other. Therefore, this study will focus on evaluating the roles of various brand equity constructs (including brand loyalty, brand association, brand awareness and brand image) in mediating the interrelation among electronic word of mouth and the dimensions of brand equity in the context of social media. There were total of 300 usable questionnaires were collected in this research. The finding revealed that there is an indirect inter-relationship between electronic word of mouth and the dimension of brand equity, mediated by the respective various brand equity constructs.
\end{abstract}

Keywords: electronic word of mouth, brand awareness, brand association, brand loyalty, brand image, perceived quality, brand equity

\section{Introduction}

Successful brands recognize the power of social media in creating, sustaining, communicating and interacting with potential users in today's interactive marketplace (Bulearca \& Bulearca, 2010). In the world of social media, fast interaction and communication have steered businesses to become more under the spot lights of consumers. Through the social media, consumers can express their views to millions of people in only seconds in which this phenomenon indicates consumers are now more used to having news brought to them in comparing to the searching for information (Qualman, 2009, p. 9). The changes in communication have encouraged many businesses to adopt Web 2.0 strategies and these strategies can be communicated via different online platforms of the social media, including social networking site, open virtual world, brand sponsored virtual worlds, images and videos areas and social news. Based on the findings of Anderson (2008) and Hung and Li (2007), one of the most powerful channels in the social media is word of mouth. Duan, Gu and Whinston (2008) assert that word of mouth is indeed a powerful tool in delivering the information. Furthermore, the impact of electronic word of mouth on the various brand equity constructs have been examined in the extant literature by focusing on Generation Y as the targeted respondents (Norjaya Mohd. Yasin \& Abdul Rahman Zahari, 2011). However, the study carried out by Norjaya Mohd. Yasin and Abdul Rahman Zahari (2011) primarily focusing on evaluating the impacts of various brand equity elements in mediating the inter-relationship between electronic word of mouth and brand equity. However, this research discovers that there is insufficient in the extant literature in studying the impacts of different brand equity constructs (including brand loyalty, brand association, brand awareness, brand image and perceived quality) in mediating the inter-relationship between electronic word of mouth and the dimensions of brand equity based on the context of social media. Thus, this research paper aims to find out the roles of various brand equity constructs (including brand loyalty, brand association, brand awareness, brand image and perceived quality) in mediating the inter-relationship between electronic word of mouth and the dimensions of brand equity based on the context of social media among the international students in Malaysia. 


\section{Literature Review}

\subsection{Social Media}

Based on Kaplan and Haenlein (2010, p. 565), social media is an internet based program that helps consumers to share opinions, information, experiences, and perspectives in which the internet based programs can be explored through the social networking sites, blogs and content areas. Social media empowers customers to express their perceptions about products or services in the public domain. The messages that are broadcasted publicly via social media enhance the market visibility that results in customer's greater potential of negotiation (Constantinides \& Fountain, 2007; Ind \& Riondion, 2001). Poynter (2008) argues that users can greatly affected by the information that appeared in the social networking sites. Moreover, DEL Worldwide (2008) discovers that $70 \%$ of the consumers approaches social media sites to access products and brands related information and $49 \%$ of them finalise their purchase decisions based on information they have retrieved from the social networking sites.

\subsection{Brand Equity}

Brand equity can be defined as the financial and marketing values connected to the brand in the market place (Pride \& Ferrell, 2003, p. 299). Brand equity consists of brand name, brand awareness, brand loyalty, brand association, perceived quality and other actual proprietary brand assets. Lassar, Mittal and Arun (1995) evaluate brand equity from the financial and customer points of view. Financial perspective usually points out the value of brand equity that company embedded in the balance sheet (Feldwick, 1996). On the other hand, Customer perspective points out that the customer's added value to the brand equity from the marketing decision making aspect (Kim, Kim \& An, 2003). This research paper would concentrate on the customer perspective to evaluate brand equity. Aaker (1991) defines brand equity in five different dimensions that brings value for brand equity, such as brand awareness, brand association, brand loyalty, perceived quality and unidentified actual proprietary brand assets. But, some researchers have divided brand equity into four dimensions, consisting brand loyalty, brand awareness, brand association and perceived quality (Aaker \& Joachimsthaler, 2000). However, other researcher classifies the brand equity into the other four different dimensions, consisiting brand knowledge, perceived quality, brand loyalty and brand image (Keller, 1993). Furthermore, Keller argues that brand knowledge consists of brand image and brand awareness. This study would like to discuss the combination of brand equity dimensions proposed by (Keller, 1993; Aaker \& Joachimsthaler, 2000). The dimensions of brand equity that would be discussed in this research encompassing brand awareness, brand association, brand loyalty, perceived quality and brand image.

\subsubsection{Brand Awareness}

Aaker (1996b) states that brand awareness acts as an important role in the branding study and it is essential and usually disregarded part of brand equity. However, brand awareness is created based on the evolution of brand recognition from the stage of an unclear sense and feeling towards a certainty that it is the only one in the product category (Aaker, 1991). Therefore, Keller (1998) defines brand awareness as the phenomenon created by the ongoing visibility, powerful association with the right product classification, buying experiences and enhancing familiarity. Furthermore, customer's ability would be influenced by the brand awareness through remembering and recognizing the brand, which is demonstrated by spotting the brand in different situations and circumstances (Atilgan, Aksoy \& Akinci, 2005; Aaker, 1991). Brand awareness is a significant catalyst in impacting the customer purchasing decision making, especially in creating three advantages, namely learning, choice and consideration advantage (Keller, 2003; Atilgan, Aksoy \& Akinci, 2005). Thus, Aaker and Joachimsthaler (2000, p. 17) and Baldauf et al. (2003) conclude that the brand awareness influences consumers' taste, perceptions and purchasing, depending on the degree of familiarity of the products and services offered. Pitta and Katsanis (1995) hold a strong position in arguing the inter-relationship between brand awareness and brand association because the establishment of brand association in the consumer's mind will be depended on the successful of embedding brand awareness in the consumer's mind. Furthermore, Atilgan and Pappu (2005) also support the relationship between brand awareness and brand association in their study.

\subsubsection{Brand Association}

Lasser et al. (1995) define brand association as positive feelings of consumer towards the brand based on the relative degree of brand strength. Hamann et al. (2007) state that buyers usually are willing to purchase branded goods at the premium costs due to the emotional bonding with the reputable brands. According to Keller (1998), there are three types of brand association: attitudes (customer's overall appraisal of the brand), benefits (the thought customers have about a particular products or a service that would benefit them, such as sensible advantages, outstanding advantages, and experimental benefits) and attributes (including product related and 
non-product related attributes, for instance feeling, price, experience, and brand personality). Consumers may use brand association to help them to envisage a product (OLoughlin \& Szmigin, 2005). James (2005) argues that the greater level of brand association will boost brand equity. Furthermore, brand loyalty can be enhanced if customers have higher degree of brand association (Yoo, Donthu \& Lee, 2000). Meanwhile, Atilgan et al. (2005) also indicate that the more optimistic and satisfactory of customers associated towards a brand, it will lead to create more loyalty for the customers toward a brand and vice versa.

\subsubsection{Brand Loyalty}

Brand loyalty can be defined as a constant purchasing or re-patronizing a preferred good or service over time (Aaker, 1991). Customers who are loyal to a particular brand will consider that brand as their preferred selection and they are less likely to be targeted by price war and they do not easily shift to other brands (Mark et al., 2007). Consequently, brand loyalty is always recognized by productive and positive consumers toward a brand, which leads to constant purchasing of products and services over time (Urde, 1994). However, brand loyalty can be affected by the consumer's direct and indirect assessment and evaluation of the particular brand that based on the various sources, such as personal experiential learning and word of mouth (Keller, 1993; Delgado Ballaster and Munuera Aleman, 2005). In due respect, brand loyalty can be enhanced via a higher degree of brand equity (Aaker, 1991; Atilgan et al., 2005; Baldauf et al, 2003). In addition, researchers state that there is a constructive correlation between customer loyalty and brand image (Strategic Marketing and Research Techniques, 2005).

\subsubsection{Brand Image}

According to Aaker (1991), brand image acts as an essential role in marketing by creating value through distinguishing the brand, creating purchasing rationales, constructing sense and feeling, and helping consumers in processing information. However, Dobni and Zinkhan (1990) assert that there is no agreement relating to the brand image definition. Roy and Banerjee (2007) describe brand image as the customer's impression and feeling regarding to the brand. Park and Arinivasan (1994) and Bearden and Etzel (1982) argue that brand image is highly associated with the specific product category and feature. Brand image is an essential factor in determining the consumer buying behaviour (Burmann et al., 2008). Richardson et al (1994) assert that buyers rely on brand image of specific product in obtaining overall product perception; they believe that consumers with high brand image on specific product may assume that as a prime value and quality. Experiment research has been done by Jacoby et al (1971) shown that brand image significantly impact consumers' perception quality and value.

\subsubsection{Perceived Quality}

Perceived quality can be defined as the whole customer's perception in related to the comparative performance of the goods and services in comparing with the competing offerings (Aaker, 1991). In other words, perceived quality can be described as the recognition of product capability to provide customer's satisfaction compared to other existing competing offerings. Therefore, Baldauf et al (2003) believe that high quality of the product can provide competitive advantage and is vital source for firms. Furthermore, high product quality provides the possibility of charging a price over the market rate to enable the company to earn huge profits. However, superior quality is not a core competency in many markets but it is an essential to go into the competition (Urde, 1994). According to De Chernatony and Drury (2006), perceived brand quality does influence the brand image.

\subsection{Word of Mouth}

Duan et al (2008) define online word of mouth (e WOM) as an Internet platform to share the positive or negative reports between the existing users and future customers. Duan et al. (2008) also believe that word of mouth is one of the powerful options of sharing information among the peoples because word of mouth is the procedure of moving opinions and views from one individual to the next. Word of mouth is normally associated with the personal encounters and assessments of a company or its product (Zhang, Ye, Law \& Li, 2010). Word of mouth performs a big part in the customer purchasing decisions (Richins Root-Shaffer, cited in Jansen et al. 2009, p. 2169) because word of mouth provides a channel for consumers to share perceptions, views, or feedbacks about the businesses, goods, or services. This argument is supported by the research carried out by the Nielsen in 2007 in which $78 \%$ of the customers depend on the recommendation from the online word of mouth to make their decisions.

\subsection{Mediated Hypotheses}

\subsubsection{Relationship among Electronic Word of Mouth, Brand Association and Brand Awareness}

James (2005) argues that the level of brand association is positively related to the degree of brand equity. Pitta and Katsanis (1995) state that brand awareness will determine brand association. Study done by Ha (2004) 
indicates that electronic word of mouth has a particular strength, which can raise the awareness, and subsequently affect the consumer behaviour. In addition, word of mouth can positively enhance brand awareness and brand association respectively (Page \& Lepkowska-White, 2002). According to Jansen et al. (2009), electronic word of mouth plays a vital role in expressing brand satisfaction and would have impact on brand awareness. However, theoretical interrelationships among electronic word of mouth, brand association and brand awareness have been proven, but mediating relationship among these three constructs have not been evaluated. For that reason, this research intends to identify the interrelationship between electronic word of mouth and brand association mediated by brand awareness via hypothesis 1 .

H1: Brand awareness mediates the relationship between electronic word of mouth and brand association.

\subsubsection{Relationship among Electronic Word of Mouth, Brand Loyalty and Brand Association}

The studies from Atilgan et al. (2005) and Yoo et al. (2000) indicate that more optimistic and satisfactory of customers associated towards a brand, it will lead to create more loyalty for the customers toward a brand and vice versa. Mazzarol, Sweeny and Startar (2007) suggest that the electronic word of mouth is a new approach to achieve competitive advantage in the market place; it can be treated as an indicator of customer's brand loyalty. Srinivasan et al. (2002) establish the positive relationship between brand loyalty and word of mouth by arguing that one of the behavioural results of the brand loyalty is coming from positive word of mouth. Hagel and Armstrong (1997) and Dick and Basu (1994) state that customers with high degree of loyalty are more incline to capture favorable word of mouth. Based on Page and Lepkowska-White (2002), word of mouth can positively enhance brand association and subsequently brand association creates impact on brand loyalty. However, theoretical interrelationships among electronic word of mouth, brand loyalty and brand association have been proven, but mediating relationships among these three constructs have not been evaluated. For that reason, this research intends to identify the interrelationship between electronic word of mouth and brand loyalty that mediated by brand association through hypothesis 2 .

$\mathrm{H} 2$ : Brand association mediates the relationship between electronic word of mouth and brand loyalty.

\subsubsection{Relationship among Electronic Word of Mouth, Brand Image and Brand Loyalty}

Yoo et al (2000, p. 17) have stated that there is a strong positive inter-relationship between brand loyalty and brand image. Yoo et al. (2000) also assert that the more satisfactory and optimistic customers are toward a brand, it would bring more positive image for the customers toward a brand. Brand image and perception could be influenced in massive scale by consumers with the help of electronic word of mouth through the social media networks (Reynolds, 2006; Urban, 2005; Jansen et al., 2009). Hanna et al. (2011) also state that active consumers can play vital role in creating and marketing the content of brands. In fact, consumers with the help of technology can increase the anti-brand content on the Internet; as a result, negative word of mouth is more visible than before (Kucuk, 2010). However, theoretical interrelationships among electronic word of mouth, brand image and brand loyalty have been proven, but mediating relationship among these three constructs have not been evaluated. For that reason, this research intends to identify the interrelationship between electronic word of mouth and brand image that mediated by brand loyalty through hypothesis 3 .

H3: Brand loyalty mediates the relationship between electronic word of mouth and brand image.

\subsubsection{Relationship among Electronic Word of Mouth, Perceived Quality and Brand Image}

Experiment research has been done by Jacoby et al. (1971) shown that brand image creates significantly impact on the consumers' perceptions of quality and value. Numerous studies shown that brand image acts as a quick source or representative of value and quality for consumers (Shimp \& Bearden, 1982; Rao \& Monroe, 1989). Kotler and Armstrong (1996) assert that brand image can be used by consumer to infer the perceived quality of the product. Furthermore, research done by Richardson, Dick and Jain (1994) discovers the same results as consumers with high brand image usually infer product as a high quality and value. According to Reynolds (2006), Urban (2005) and Hartline and Jones (1996), electronic word of mouth could influence the consumer towards the brand image and perception because electronic word of mouth is an essential part of consumer expression (in term of expressing brand hapiness) that may influence the brand image of the product. However, there is an argument presented by Herr et al (1991) in which they view word of mouth can create different perceptions amongst customers. If the word of mouth is negative, customers will have a bad impression of the product quality. On the other hands, if the word of mouth is positive, then customers will have a good impression of the quality. Electronic word of mouth has turned into more non- linear and the study asserts that it has had diverse impacts in influencing the value and quality of a particular product (Meyer \& Johnson, 1995). Theoretical interrelationships among electronic word of mouth, perceived quality and brand image have been 
proven, but mediating relationship among these three constructs have not been evaluated. For that reason, this research intends to identify the interrelationship between electronic word of mouth and perceived quality that mediated by brand image through hypothesis 4 .

H4: Brand image mediates the relationship between electronic word of mouth and perceived quality.

\subsection{Proposed Conceptual Framework}

Proposed conceptual framework for this research paper has been illustrated in Figure 1. The figure illustrates the relationships between the electronic word of mouth and the respective dimensions of brand equity.

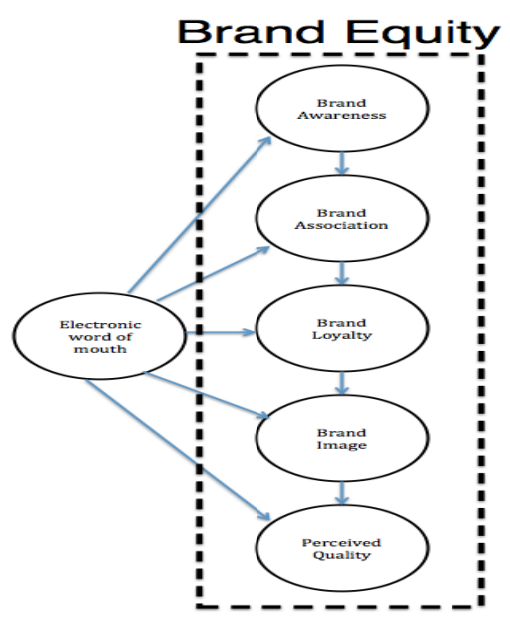

Figure 1. Proposed conceptual framework

\section{Research Methodology}

\subsection{Research Design}

In terms of research design, researcher applied descriptive research design because there is a clear-tested hypothesis that leads to statistical findings and concludes the results (Malhotra, 2004).

\subsection{Questionnaire Design}

In this research paper, questionnaire contains two different sections of question, namely section 1 and section 2 . Variables in section 1 evaluating electronic word of mouth and five brand equity dimensions (brand association, brand image, brand loyalty, perceived quality, brand awareness). The variables that appear in the section two of the questionnaire contain demographic profile, including gender, nationality, age, martial status and highest academic qualifaction level. Measurement scales for brand awareness variable were adopted from Atilgan et al. (2005) and Yoo et al. (2000). Both variables of brand association and brand loyalty were adopted from Kim and Kim (2005) and Yoo et al. (2000). Brand image and perceived quality were selected from Kim and Kim (2005). Finally, measurement scales for electronic word of mouth variable were adopted from Citrin (2001), Wixom and Todd (2005) and Wu and Shaffer (1987). Five- point likert scales have been selected to measure all constructs in this research paper with the measurement from strongly disagree to strongly agree.

\subsection{Sampling Design}

In terms of sampling, this research paper focused on full time business students in one of the private universities in Malaysia as a target population. The total number of 330 students was selected as the sampling size. For the selection of sampling technique, researcher used convenience-sampling technique to select potential respondents.

\subsection{Administration of Survey}

In this research, researcher conducted drop-off survey technique to collect the information. Copies of questionnaire in the form of self-administered survey have been given to the students to ensure the privacy and confidentialiy of the respondents are protected. Furthermore, a pilot test had been conducted with 30 potential respondents to ensure the quality and reliability of the measurement scales for all the constructs are upholded before the actual survey being implemented. Out of 330 copies of questionnaire that have been distributed among potential respondents, 300 questionnaires were collected. 30 sets of questionnaires were considered 
unfinished because they were incompleted and consider it as respondents were not willing to participate or they are not take the survey serious (Sekaran, 2003). Therefore, the total numbers of 300 usable questionnaires were used (91.6 percent) for the purpose of data analysis in this research and subsequently researcher used SPSS software version (20) to analysis the data.

\section{Research Results}

\subsection{Demographic Profile Analysis}

According to the finding, out of 300 credible respondents, gender distribution of the respondents contain $50 \%$ male and 50\% female. In terms of age distribution, age 26 to 30 years old was the highest and oldest group with $42.3 \%$. Age 21 to 25 years old with $38.7 \%$, followed by age 31 to 35 years old with $14 \%$, age 20 years old or less is the lowest age group with $3.3 \%$ and age 30 to 40 years old with $1.4 \%$. In terms of highest academic level majority of the students were in master degree with $51 \%$ followed my bachlore's degree with $41.7 \%$ and finally diploma degree with $4.7 \%$.

\subsection{Reliability Test}

Based on Cavana et al (2001), reliability test is used to make sure the measures are stable and consistent. Furthermore, Hair et al. (2003) mention that scale can be reliable while measurements are repeated and the outcomes must be consistent. For the consistency reliability of the items among the constructs, Cronbach alpha reliability analysis test would be used to evaluate the construct reliability. Based on Cavana et al. (2001), Cronbach alpha with the value of greater than 0.70 is considered as an acceptable and good. According to Table 2, the values of Cronbach Alpha for all of the six tested constructs were greater than 0.70, as according to the guidelines from Cavana et al. (2001). Therefore, it can be concluded that all the measurement scales for the constructs are reliable, stable and consistent.

Table 2. Reliability of the constructs

\begin{tabular}{ll}
\hline Constructs & Composite Reliability \\
\hline Electronic Word of Mouth & 0.871 \\
Brand Awareness & 0.914 \\
Brand Association & 0.795 \\
Brand Loyalty & 0.821 \\
Brand Image & 0.780 \\
Perceived Quality & 0.838 \\
\hline
\end{tabular}

Source: Developed for this research.

\subsection{Validity Test}

Construct validity is used to measure the validity of dimensions (Cavana et al., 2001) and factor analysis will be utilized to measure the validity of the constructs. Table 3 shown the results of factor analysis. Malhotra (2004) states that when the value of KMO (Kasier Meyer Olkin) is between 0.5 and 1.0, the factor analysis is appropriate. On the other hands, the factor analysis is not appropriate if the value of KMO is below 0.5. According to the results indicated in Table 3, the value of the KMO was 0.850 (that is between 0.5 and 1.0) in which means factor analysis is appropriate. Furthermore, "statistical test for Bartlett test of sphericity was significant $(\mathrm{p}=0.000$; d.f. $=351)$ for all the correlations within a correlation matrix (at least for some of the constructs)" (Kwek, Lau, \& Tan, 2010, p. 69). Results from the principle components analysis and VARIMAX procedure in orthogonal rotation which were adopted in the factor analysis show that the Eignvalues for all the constructs are bigger than 1. Based on Table 3, brand image with 1.544 is the lowest to brand awareness with 7.971 is the highest. According to Table 3, factor loading for all the constructs were greater than 0.50 . All the related items that measure the particular construct are loaded together with the value of factor loading more than 0.5 . Thus, this can be concluded the measurement scales have a higher degree of convergent validity. The result of discriminant validity that shown in Table 3 indicates that items were not cross loading and supported different constructs respectively because whole items were allocated according to the different constructs. 
Table 3. Factors identified by principal components factor analysis

\begin{tabular}{|c|c|c|c|c|c|}
\hline Factor's Name & Variable & $\begin{array}{l}\text { Factor } \\
\text { Loading }\end{array}$ & Eigen-value & $\begin{array}{l}\text { Percentage } \\
\text { of Variance Explained }\end{array}$ & $\begin{array}{l}\text { Cronbach's } \\
\text { Reliability } \\
\text { Coefficients }\end{array}$ \\
\hline \multirow{5}{*}{$\begin{array}{l}\text { Brand Awareness } \\
\text { (BA) }\end{array}$} & BA 1 & 0.872 & \multirow{5}{*}{7.971} & \multirow{5}{*}{14.80} & \multirow{5}{*}{0.914} \\
\hline & BA 2 & 0.851 & & & \\
\hline & BA 3 & 0.871 & & & \\
\hline & BA 4 & 0.872 & & & \\
\hline & BA 5 & 0.770 & & & \\
\hline \multirow{5}{*}{$\begin{array}{l}\text { Electronic word of mouth } \\
(\text { EWM) }\end{array}$} & EWM 1 & 0.777 & \multirow{5}{*}{2.720} & \multirow{5}{*}{12.878} & \multirow{5}{*}{0.871} \\
\hline & EWM 2 & 0.836 & & & \\
\hline & EWM 3 & 0.777 & & & \\
\hline & EWM 4 & 0.801 & & & \\
\hline & EWM 5 & 0.823 & & & \\
\hline \multirow{5}{*}{ Brand Loyalty (BL) } & BL 1 & 0.646 & \multirow{5}{*}{2.598} & \multirow{5}{*}{11.365} & \multirow{5}{*}{0.821} \\
\hline & BL 2 & 0.736 & & & \\
\hline & BL 3 & 0.563 & & & \\
\hline & BL 4 & 0.801 & & & \\
\hline & BL 5 & 0.823 & & & \\
\hline \multirow{5}{*}{$\begin{array}{l}\text { Brand Association } \\
\text { (BAss) }\end{array}$} & BAss 1 & 0.873 & \multirow{5}{*}{1.928} & \multirow{5}{*}{11.035} & \multirow{5}{*}{0.795} \\
\hline & BAss 2 & 0.852 & & & \\
\hline & BAss 3 & 0.871 & & & \\
\hline & BAss 4 & 0.874 & & & \\
\hline & BAss 5 & 0.755 & & & \\
\hline \multirow{4}{*}{ Perceived Quality (PQ) } & PQ 1 & 0.782 & \multirow{4}{*}{1.697} & \multirow{4}{*}{10.054} & \multirow{4}{*}{0.838} \\
\hline & PQ 2 & 0.745 & & & \\
\hline & PQ 3 & 0.783 & & & \\
\hline & PQ 4 & 0.805 & & & \\
\hline \multirow{3}{*}{ Brand Image (BI) } & BI 1 & 0.698 & \multirow{3}{*}{1.544} & \multirow{3}{*}{8.235} & \multirow{3}{*}{0.780} \\
\hline & BI 2 & 0.828 & & & \\
\hline & BI 3 & 0.808 & & & \\
\hline
\end{tabular}

Note. KMO Measure of Sampling Adequacy $=0.845 ; \mathrm{p}=0.0001(\mathrm{p}<0.05) ; \mathrm{df}=351$; Cumulative Percentage Rotation Sums of Squared Loadings $=$ 68.368 .

Source: Developed for this research.

\subsection{Mediated Regression Analysis}

According to Howitt and Cramer (2011a), when variable one and variable two cause or precedue variable three (called dependent variable), mediational analysis would apply. For testing hypothesis 1, hypothesis 2, hypothesis 3 and hypothesis 4, Baron and Kenny (1996) propose three steps approach in evaluating the mediating effect, known as mediated regression analysis. Based on Baron and Kenny (1986, p.1177), the following conditions must hold to establish mediation: first of all, in first step the independent variable should influence the mediator; in second step, the dependent variable should be influenced by independent variable; and lastly in third step, the mediator should influence the dependent variable. However, if all these conditions move in the predict condition, then the impact of independent variable in step three on dependent variable must be less than in equation two. Table 4(a),(b),(c),(d) shows the three steps procedure that advocated by Baron and Kenny (1986) in identifying the role of mediator. 
4.4.1 Relationship among Electronic Word of Mouth, Brand Association and Brand Awareness (H1)

Table 4(a). Result of mediated multiple regression (mediator analysis) (H1)

\begin{tabular}{lccc}
\hline \multirow{2}{*}{ Independent Variable } & Brand Awareness (Mediator) & \multicolumn{2}{c}{ Brand Association (Dependent Variable) } \\
\cline { 2 - 4 } & Model 1 & Model 2 & Model 3 \\
\hline Electronic word of mouth & $0.240 *\left(1^{\text {st }}\right.$ equation $)$ & $0.270^{*}\left(2^{\text {nd }}\right.$ equation $)$ & $0.210^{*}\left(3^{\text {rd }}\right.$ equation $)$ \\
\hline Brand Awareness & & & $0.252^{*}\left(3^{\text {rd }}\right.$ equation $)$ \\
\cline { 2 - 4 } & & &
\end{tabular}

Source: Developed for this research.

Result from Table 4(a) illustrated that; electronic word of mouth (independent variable) significantly impacted the brand awareness (mediator) in equation one. In equation two, electronic word of mouth (independent variable) significantly impacted the brand association (dependent variable). Electronic word of mouth (independent variable) and brand awareness (mediator), both significantly affected brand association (dependent variable). Unstandardized beta coefficient value of electronic word of mouth in equation three is smaller that beta value of electronic word of mouth in equation two $(0.210<0.270$, reduced by $0.06(0.270-0.210))$. This reduction in value indicates the hypothesis 1 (H1) is supported. Finding confirmed that brand awareness acts as a mediator in mediating the relationship between electronic word of mouth and brand association.

4.4.2 Relationship among Electronic Word of Mouth, Brand Loyalty and Brand Association (H2)

Table 4(b). Result of mediated multiple regression (mediator analysis) (H2)

\begin{tabular}{lccc}
\hline Independent Variable & Brand Association (Mediator) & \multicolumn{2}{c}{ Brand Loyalty (Dependent Variable) } \\
\cline { 2 - 4 } & Model 1 & Model 2 & Model 3 \\
\hline Electronic word of mouth & $0.270^{*}\left(1^{\text {st }}\right.$ equation $)$ & $0.292^{*}\left(2^{\text {nd }}\right.$ equation $)$ & $0.210^{*}\left(3^{\text {rd }}\right.$ equation $)$ \\
\hline Brand Association & & & $0.353^{*}\left(3^{\text {rd }}\right.$ equation $)$ \\
\hline
\end{tabular}

Note. ${ }^{*} \mathrm{p}<0.05$;

Source: Developed for this research.

Result from Table 4(b) illustrated that electronic word of mouth (independent variable) significantly impacted the brand association (mediator) in equation one. In equation two, electronic word of mouth (independent variable) significantly impacted the brand loyalty (dependent variable). Electronic word of mouth (independent variable) and brand association (mediator), both significantly affected brand loyalty (dependent variable). Unstandardized beta coefficient value of electronic word of mouth in equation three is smaller that unstandardized beta coefficient value of electronic word of mouth in equation two $[0.210<0.292$, reduced by $0.082(0.292-0.210)]$. This reduction in value indicates the hypothesis 2 (H2) is supported. Finding confirmed that brand association acts as a mediator in mediating the relationship between electronic word of mouth and brand loyalty.

4.4.3 Relationship among Electronic Word of Mouth, Brand Image and Brand Loyalty

Table 4(c). Result of mediated multiple regression (mediator analysis) (H3)

\begin{tabular}{|c|c|c|c|}
\hline \multirow[t]{2}{*}{ Independent Variable } & Brand Loyalty (Mediator) & \multicolumn{2}{|c|}{ Brand Image (Dependent Variable) } \\
\hline & Model 1 & Model 2 & Model 3 \\
\hline Electronic word of mouth & $0.292 *\left(1^{\text {st }}\right.$ equation $)$ & $0.166^{*}\left(2^{\text {nd }}\right.$ equation $)$ & $0.210 *\left(3^{\text {rd }}\right.$ equation $)$ \\
\hline Brand loyalty & & & $0.188 *\left(3^{\text {rd }}\right.$ equation $)$ \\
\hline
\end{tabular}


Result from Table 4(c) illustrated that electronic word of mouth (independent variable) significantly impacted the brand loyalty (mediator) in equation one. In equation two, electronic word of mouth (independent variable) significantly impacted the brand image (dependent variable). Electronic word of mouth (independent variable) and brand loyalty (mediator), both significantly affected brand image (dependent variable). Unstandardized beta coefficient value of electronic word of mouth in equation three is smaller that unstandardized beta coefficient value of electronic word of mouth in equation two $(0.210<0.166$, reduced by $0.044(0.210-0.166))$. This reduction in value indicates the hypothesis hypothesis 3 (H3) is supported. Finding confirmed that brand loyalty acts as a mediator in mediating the relationship between electronic word of mouth and brand image.

4.4.4 Relationship among Electronic Word of Mouth, Perceived Quality and Brand Image

Table 4(d). Result of mediated multiple regression (mediator analysis) (H4)

\begin{tabular}{lccc}
\hline Independent Variable & Brand Image (Mediator) & \multicolumn{2}{c}{ Perceived Quality (Dependent Variable) } \\
\cline { 2 - 4 } & Model 1 & Model 2 & Model 3 \\
\hline Electronic word of mouth & $0.166 *\left(1^{\text {st }}\right.$ equation $)$ & $0.225^{*}\left(2^{\text {nd }}\right.$ equation $)$ & $0.173 *\left(3^{\text {rd }}\right.$ equation $)$ \\
\hline Brand Image & & & $0.311^{\text {rd }}$ equation $)$ \\
\hline
\end{tabular}

Note. ${ }^{*} \mathrm{p}<0.05$;

Source: Developed for this research.

Result from Table 4(d) illustrated that electronic word of mouth (independent variable) significantly impacted the brand image (mediator) in equation one. In equation two, electronic word of mouth (independent variable) significantly impacted the perceived quality (dependent variable). Electronic word of mouth (independent variable) and brand image (mediator), both significantly affected perceived quality (dependent variable). Unstandardized beta coefficient value of electronic word of mouth in equation three is smaller that unstandardized beta coefficient value of electronic word of mouth in equation two $(0.225<0.173$, reduced by $0.52(0.225-0.173))$. This reduction in value indicates the hypothesis $4(\mathrm{H} 4)$ is supported. Finding confirmed that brand image acts as a mediator in mediating the relationship between electronic word of mouth and perceived quality.

\section{Conclusion}

\subsection{Implication of Research Findings}

\subsubsection{Theoretical Implication}

Finding from this research shows that brand awareness acts as a mediator between electronic word of mouth and brand association; brand association acts as a mediator between electronic word of mouth and brand loyalty; brand loyalty acts as a mediator between electronic word of mouth and brand image; and finally brand image acts as a mediator between electronic word of mouth and perceived quality.

\subsubsection{Managerial Implication}

Findings from this study provide some insights for the industry. Firstly, with the use of electronic word of mouth via the social media context, companies can create and enhance brand equity of products and services and subsequently lead to attract customers. However, marketers must keep in mind that the electronic word of mouth is a great tool that influences brand equity of product and service in the social media. While the viral marketing information is seem to be trusted by consumers and users, marketers should prioritize and implement them in their advertising strategy. Furthermore, marketers must make sure that target audience will receive their marketing communications at right time and right place because the target audience in future will act as an opinion leader to the young consumers. In conclusion, the marketers should prioritize electronic word of mouth as their strategy in the social media because it does show that electronic word of mouth has significant direct and indirect relationships with the dimensions of brand equity in the social media context.

\subsection{Limitations of Research}

Outcomes from this study might be viewed with some limitations. Results in this study was analysed by using cross sectional data in which the cross section a data is solely capable to disclose the net impact of independent variable regardings to a certain dependent variable at a particular time frame (Cavana et al., 2001). Furthermore, as a result of rooted limitation of cross-sectional study, the outcomes in this research will not unable to describe 
the flow of a typical pattern of the findings (Easterby-Smith, Thorpe \& Lowe, 2003, p. 45). In addition, utilisation of convenience sampling techniques in this study has restricted the generalizable of the study outcomes.

\subsection{Recommendation for Future Study}

In view of the above limitations, some recommendations are suggested for the future research. The limitation of the cross-sectional study will be able to overcome by using longitudinal study in which the longitudinal study will help to identify the trend of the analysis through repeating in measuring the samples over a preset duration of the time frame (Burns and Bush, 2003). In addition, probability sampling technique is recommended for the future study for the purpose of improving the validity and generalization of the research outcomes by reducing the restriction of generalization from the study.

\section{References}

Aaker, D. A. (1991). The value of brand equity. Journal of Business Strategy, 13(4), 27-33.

Aaker, D. A. (1996). Managing brand equity: Capitalizing on the value of the brand name. New York: The Free Press.

Aaker, D. A. (1996). Measuring brand equity across products and markets. California Management Review, $38(3), 102-120$.

Aaker, D. A., \& Joachimsthaler, E. (2000). Brand Leadership. New York: The Free Press

Anderson, S. (2008). Using social networks to market. Rough Notes, 151(2), 114-115.

Atilgan, E., Aksoy, S., \& Akinci, S. (2005). Determinants of brand equity: A verification approach in the beverage industry in Turkey'. Marketing Intelligence \& Planning, 23(3), 237-248. http://dx.doi.org/10.1108/02634500510597283

Baron, R. M., \& Kenny, D. A. (1986). The moderator-mediator variable distinction in social psychological research: Conceptual, strategic and statistical considerations. Journal of Personality \& Social Psychology, 51, 1173-1182. http://dx.doi.org/10.1037/0022-3514.51.6.6.1173

Baldauf, A., Cravens, K. S., \& Binder, G. (2003). Performance consequences of brand equity management, evidence from organizations in the value chain. Journal of Product and Brand Management, 12(4), 220-236. http://dx.doi.org/10.1108/10610420310485032

Bearden, W. O., \& Etzel, M. J. (1982). Reference group influence on product and brand purchase decisions. Journal of Consumer Research, 9, 183-194. http://dx.doi.org/10.1086/208911

Bulearca, M., \& Bulearca, S. (2010). Twitter: A viable marketing tool for SMEs. Journal of Global Business \& Management Research, 2(4), 296-309.

Burmann, C., Schaefer, K., \& Maloney, P. (2008). Industry image: Its impact on the brand image of potential employees. Journal of Brand Management, 16(3), 159-176.

Cavana, R. Y., Delahaye, B. L., \& Sekaran, U. (2001). Applied business research: Qualitative and quantitative methods. Queensland: John Wiley \& Sons.

Citrin, A. V. (2001). Information quality perceptions: The role of communication media characteristics. Information and Learning, 17, 1-143.

Constantinides, E., \& Fountain, S. (2007). Web 2.0: Conceptual foundations and marketing issues. Journal of Direct Data and Digital Marketing Practice, 9(3), 231-244.

DEI Worldwide, E. (2008). The impact of social media on purchasing behaviour, Engaging Consumers Online. Retrieved 23/03, 2011, from http://www.deiworldwide.com/files/DEIStudy\%20ConsumersOnline-Summary.pdf

Delgado-Ballaster, E., \& Munuera-Aleman, J. L. (2005). Does brand trust matter to brand equity? Journal of Product and Brand Management, 14(3), 187-196. http://dx.doi.org/10.1108/10610420510601058

De Chernatony, L., \& Drury, S. (2006). The effects of service brand extensions on corporate image: An empirical model. European Journal of Marketing, 40(1/2), 174-197. http://dx.doi.org/10.1108/03090560610637374

Dick, A. S., \& Basu, K. (1994). Customer loyalty: Toward an integrated conceptual framework. Journal of the Academy of Marketing Science, 22(2), 99-113. http://dx.doi.org/10.1177/0092070394222001

Dichter, E. (1985). What's in an image. Journal of Consumer Marketing, 2(1), 75-81. 
http://dx.doi.org/10.1108/eb0338824

Duana, W., Gu, B., \& Whinston, A. (2008). Do online review matter? An empirical investigation of panel data. Journal of Decision Support System, 45(4).

Dobni, D., \& Zinkhan, G. M. (1990). In search of brand image: A foundation analysis. Advances in Consumer Research, 17, 110-119.

Easterby, S. M., Thorpe, R., \& Lowe, A. (2003). Management research: An introduction. California: SAGE Publications.

Feldwick, P. (1996). Do we really need brand equity. The Journal of Brand Management, 4(1), 9-28. http://dx.doi.org/10.1108/10610420710739973

Hamann, D., William Jr, R. L., \& Omar, M. (2007). Branding strategy and consumer high-technology product. Journal of Product and Brand Management, 16(2), 98-111.

Hartline, M. D., \& Jones, K. J. (1996). Employee performance cues in a hotel service environment: Influence on perceived service quality, value, and word of mouth intentions. Journal of Business Research, 35(3), 207-215.

Herr, P. M., Kardes, F. R., \& Kim, L. (1991). Effects of word of mouth and product attribute information on persuasion: An accessibility diagnosticity perspective. Journal of Consumer Research, 17(4), 454-462.

Hung, K., Stella, H., \& Li, Y. Y. (2007). The influence of e WOM on virtual consumer communities: Social capital, consumer learning, and behavioral outcomes. Journal of Advertising Research, 47(4), 485-495.

Ha, H. Y. (2004). Factors influencing consumer perceptions of brand trust online. Journal of Product \& Brand Management, 13(5), 329-342. http://dx.doi.org/10.1108/10610420410554412

Hagel, J., \& Armstrong, A. G. (1997). Net gain: Expanding markets through virtual communities. The McKinsey Quarterly, 1, 140-153.

Hanna, R., Rohm, A., \& Crittenden, V. (2011). We're all connected: The power of the social media ecosystem. Business Horizons, 54(3), 265-273. http://dx.doi.org/10.1016/j.bushor.2011.01.007

Ind, N., \& Riondion, M. (2001). Branding on the web: A real revolution. Journal of Brand Management, 9(1), $8-19$.

Jacoby, J., Olson, J., \& Haddock, R. (1971). Price, brand name, and product composition characteristics as determinants of perceived quality. Journal of Applied Psychology, 55(6), 570-579. http://dx.doi.org/10.1037/h0032045

James, D. (2005). Guilty through association: Brand association transfer to brand alliances. Journal of Consumer Marketing, 22(1), 14-25. http://dx.doi.org/10.1108/07363760510576518

Jansen, B. J., Zhang, M., Sobel, K., \& Chowdury, A. (2009). Twitter power: Tweets as electronic word of Mouth. Journal of the Association Society for Information Science and Technology, 60(11), 2169-2188. http://dx.doi.org/10.1002/asi.21149

Kaplan, A. M., \& Michael, H. (2010). Users of the world, unite! The challenges and opportunities of social media. Business Horizons, 53(1), 59-68. http://dx.doi.org/10.1016/j.bushor.2009.09.003

Keller, K. L. (1993). Conceptualizing, measuring and managing customer based brand equity. Journal of Marketing, 57, 1-22. http://dx.doi.org/10.2307/1252054

Keller, K. L. (1998). Strategic brand management: Building, measuring and managing brand equity. London: Prentice Hall International.

Keller, K. L. (2003). Strategic brand management: Building, measuring, and managing brand equity (2nd ed.). Upper Saddle River, New Jersey: Prentice Hall.

Kim, H. B., Woo, G. K., \& An, J. (2003). The effect of consumer based brand equity on firm's financial performance. Journal of Consumer Marketing, 20(4), 335-351. http://dx.doi.org/10.1108/07363760310483694

Kotler, P., \& Armstrong, G. (1996). Principles of marketing (7th ed.). New Jersey: Prentice-Hall International, Inc.

Kucuk, S. (2010). Negative double jeopardy revisited: A longitudinal analysis. Journal of Brand Management, $18(2), 150-158$. 
Kwek, C. L., Lau, T. C., \& Tan, H. P. (2010). The effects of shopping orientations, online trust and prior online purchase experience toward customers' online purchase intention. International Business Research, 3(3), 63-76.

Lassar, W., Mittal, B., \& Arun, S. (1995). Measuring consumer based brand equity. Journal of Consumer Marketing, 12(4), 11-19. http://dx.doi.org/10.1108/07363769510095270

Malhotra, N. K. (2004). Marketing research: An applied orientation. New Jersey: Prentice-Hill.

Meyer, R., \& Johnson, E. J. (1995). Empirical generalizations in the modeling of consumer choice. Marketing Scientist, 14(3), 180-189.

Norjaya, M. Y., \& Abdul, R. Z. (2011). Does family and viral marketing have any effect on brand equity. Journal of Contemporary Marketing Review, 1(9), 19-31.

O’Loughlin, D., \& Szmigin, I. (2005). Customer perspectives on the role and importance of branding in Irish retail financial services. International Journal of Bank Marketing, 23(1), 8-27. http://dx.doi.org/10.1108/02652320510577348

Page, C., \& Lepkowska, W. E. (2002). Web equity: A framework for building consumer value in online companies. Journal of Consumer Marketing, 19(3), 231-248.

Pappu, R. (2005). Consumer-based brand equity: Improving the measurement. Journal of Product and Brand Management, 14(3), 1443-1454. http://dx.doi.org/10.1108/10610420510601012

Park, C. W., \& Arinivasan, V. (1994). A survey-based method for measuring and understanding brand equity and its extendibility. Journal of Marketing Research, (31), 271-288. http://dx.doi.org/10.2307/3152199

Pitta, D. A., \& Katsanis, L. P. (1995). Understanding brand equity for successful brand extension. Journal of Consumer Marketing, 12(4), 51. http://dx.doi.org/10.1108/07363769510095306

Pride, W. M., \& Ferrell, O. C. (2003). Marketing: Concepts and strategies. Boston, MA: Houghton Mifflin Company.

Poynter, R. (2008). Facebook: The future of networking with customers. International Journal of Market Research, 50(1), 11-12.

Rao, A., \& Monroe, K. (1989). The effect of price, brand name, and store name on buyers' perceptions of product quality: An integrative review. Journal of Marketing Research, 26(3), 351-357. http://dx.doi.org/10.2307/3172907

Reynolds, G. (2006). An army of Davids: How markets and technology empower ordinary people to beat big media, big government, and other Goliaths. Nashville, TN: Thomas Nelson.

Richardson, P., Dick, A., \& Jain, A. (1994). Extrinsic and intrinsic cue effects on perceptions of store brand quality. The Journal of Marketing, 58(4), 28-36. http://dx.doi.org/10.2307/1251914

Roy, D., \& Banerjee, S. (2007). Caring strategy for integration of brand identity with brand image. International Journal of Commerce and Management, 17(1/2), 140-148. http://dx.doi.org/10.1108/10569210710776512

Shimp, T., \& Bearden, W. (1982). Warranty and other extrinsic cue effects on consumers' risk perceptions. Journal of Consumer Research, 9(1), 38-46. http://dx.doi.org/10.1086/208894

Srinivasan, S. S., Anderson, R., \& Ponnavolu, K. (2002). Customer loyalty in E-commerce: An exploration of its antecedents and consequences. Journal of Retailing, 27, 279-295. http://dx.doi.org/10.1016/S0022-4359(01)00065-3

Strategic Marketing and Research Techniques. (1992-2008). Brand and Image Assessment. Retrieved from http://www.s-m-a-r-t.com/Exp_brandequity.htm

Urban, G. (2005). Don't just relate advocate: A blueprint for profit in the era of customer power. Upper Saddle River, NJ: Wharton School Publishing.

Urde, M. (1994). Brand orientation-a strategy for survival. Journal of Consumer Marketing, 11(3), 18-32.

Wixom, B. H., \& Todd, P. A. (2005). A theoretical integration of user satisfaction and technology acceptance. Information Systems Research, 16(1), 85-102.

Wu, C., \& Shaffer, D. (1987). Susceptibility to persuasive appeals as a function of source credibility and prior experience with the attitude object. Journal of Applied Psychology, 52, 677-688.

Yoo, B., Donthu, N., \& Lee, S. (2000). An examination of selected marketing mix element and brand equity. 
Academy of Marketing Science, 28(2), 195-211. http://dx.doi.org/10.1177/0092070300282002

Zhang, Z., Ye, Q., Law, R., \& Li, Y. (2010). The impact of e-word-of-mouth on the online popularity of restaurants: A comparison of consumer reviews and editor reviews. International Journal of Hospitality Management, 29(4), 694-700. http://dx.doi.org/10.1016/j.ijhm.2010.02.002

Appendix: Questions for all the constructs

\begin{tabular}{|c|c|}
\hline \multirow[t]{2}{*}{ Brand Awareness (BA) } & A 1: I aware this particular product/brand that appeared in the social media. \\
\hline & $\begin{array}{l}\text { BA 2: I can recognize this particular product/brand in comparison with the other competing product/brand } \\
\text { that appeared in the social media. } \\
\text { BA 3: I know how this particular product/brand looks like. } \\
\text { BA 4: Some characteristics of the particular product/brand that appeared in the social media come to my } \\
\text { mind quickly. } \\
\text { BA 5: I can quickly recall symbol or logo of the particular product/brand that appeared in the social media. }\end{array}$ \\
\hline $\begin{array}{l}\text { Electronic Word of Mouth } \\
\text { (EWM) }\end{array}$ & $\begin{array}{l}\text { EWM 1: Information about the particular product/brand that appeared in the social media is relevant. } \\
\text { EWM 2: Data about the particular product/brand that appeared in the social media is up to date. } \\
\text { EWM 3: Sources about the particular product/brand that appeared in the social media are accurate. } \\
\text { EWM 4: Information about the particular product/brand that appeared in the social media is comprehensive } \\
\text { and informative. } \\
\text { EWM 5: Data and information about the particular product/brand that appeared in the social media are } \\
\text { credible and trustworthy. }\end{array}$ \\
\hline Brand Loyalty (BL) & $\begin{array}{l}\text { BL 1: I regularly refer this particular product/brand through the social media. } \\
\text { BL 2: I usually use this product/brand as my first choice in comparison with the other product/brand. } \\
\text { BL 3: I would recommend this product/brand to others through the social media. } \\
\text { BL 4: I will not switch to another product/brand that appeared in the social media next time. } \\
\text { BL 5: I am satisfied with product/brand that appeared in the social media. }\end{array}$ \\
\hline $\begin{array}{l}\text { Brand Association } \\
\text { (BAss) }\end{array}$ & $\begin{array}{l}\text { BAss 1: This particular product/brand that appeared in the social media has its own personality. } \\
\text { BAss 2: This particular product/brand is different in comparison with the other competing product/brand that } \\
\text { appeared in the social media. } \\
\text { BAss 3: I trust the company who owns the particular product/brand that appeared in the social media. } \\
\text { BAss 4: This particular product/brand that appeared in the social media is familiar to me. } \\
\text { BAss 5: There are reasons to buy this particular product/brand over the competing product/brand that } \\
\text { appeared in the social media. }\end{array}$ \\
\hline Perceived Quality (PQ) & $\begin{array}{l}\text { PQ 1: The Webmaster provides prompt services at the promised time. } \\
\text { PQ 2: The Webmaster handles customer complained effectively. } \\
\text { PQ 3: The Webmaster is able to tell patrons exactly when the services would be performed. } \\
\text { PQ 4: The Webmaster gives individual customer attention. }\end{array}$ \\
\hline Brand Image (BI) & $\begin{array}{l}\text { BI 1: This particular product/brand has a differentiated image in comparison with the other product/brand. } \\
\text { BI 2: This particular product/brand has a clean image. } \\
\text { BI 3: This particular product/brand is well established. }\end{array}$ \\
\hline
\end{tabular}

Source: Developed for this Research.

\section{Copyrights}

Copyright for this article is retained by the author(s), with first publication rights granted to the journal.

This is an open-access article distributed under the terms and conditions of the Creative Commons Attribution license (http://creativecommons.org/licenses/by/3.0/). 